\title{
Damage to the Bases in DNA Induced by Stimulated Human Neutrophils
}

Janis H. Jackson," Ewa Gajewski, Ingrid U. Schraufstatter," Paul A. Hyslop," Alfred F. Fuciarelli,"

Charles G. Cochrane, * and Miral Dizdaroglu*

*Department of Immunology, Research Institute of Scripps Clinic, La Jolla, California 92037; ${ }^{\ddagger}$ Center for Chemical Technology, National Institute of Standards and Technology, Gaithersburg, Maryland 20899

\section{Abstract}

Leukocyte-induced DNA damage may partially account for the known association between chronic inflammation and malignancy. Since elucidation of the chemical nature of leukocyteinduced DNA damage may enhance our understanding of the mechanisms underlying leukocyte-induced DNA damage and the carcinogenesis associated with inflammation, the present study was undertaken to characterize the chemical modifications that occur in DNA exposed to stimulated human neutrophils. Calf thymus DNA was exposed to phorbol myristate acetate (PMA)-stimulated neutrophils in the presence or absence of exogenously added iron ions. DNA samples were subsequently hydrolyzed, derivatized and analyzed by gas chromatography-mass spectrometry with selected-ion monitoring. A variety of base modifications including cytosine glycol, thymine glycol, 4,6-diamino-5-formamidopyrimidine, 8-hydroxyadenine, 2,6-diamino-4-hydroxy-5-formamidopyrimidine, and 8-hydroxyguanine were identified. The yield of these various base products was increased by the addition of iron ions. Specifically, in the presence of physiologic quantities of iron ions, $\sim 7$ of every 1,000 DNA bases were modified. Addition of the superoxide anion scavenger, superoxide dismutase, the hydrogen peroxide scavenger, catalase, the hydroxyl scavenger, dimethylsulfoxide, or the iron chelator, deferoxamine, to DNA mixtures containing PMA, neutrophils, and iron ions, greatly decreased the yield of the damaged DNA base products. Our results indicate that stimulated human neutrophils can damage each of the four bases in DNA. It is likely that hydroxyl radical, generated via an iron catalyzed Haber-Weiss reaction, mediates neutrophil-induced DNA base damage, since: $(a)$ the chemical structure of neutrophil-induced DNA base damage is consistent with a hydroxyl radical-mediated mechanism, (b) hydroxyl radical generated via ionizing radiation in aqueous solution produces DNA base modifications that are identical to neutrophil-induced DNA base modifications, $(c)$ iron ions increase neutrophil-induced DNA base damage, and $(d)$ iron chelators or scavengers of superoxide anion, hydrogen peroxide or hydroxyl radical decrease neutrophil-induced DNA base damage.

Address reprint requests to Dr. Jackson, Scripps Clinic and Research Foundation, 10666 North Torrey Pines Road, Box IMM 12, La Jolla, CA 92037. 1989

Received for publication 11 July 1988 and in revised form 7 June

J. Clin. Invest.

(C) The American Society for Clinical Investigation, Inc.

0021-9738/89/11/1644/06 \$2.00

Volume 84, November 1989, 1644-1649

\section{Introduction}

Chronic inflammation is associated with an increased incidence of malignancy (1-4). This association has led to speculations that inflammatory leukocytes might contribute to carcinogenesis, and this premise is supported by a recent study that demonstrated that stimulated neutrophils can transform cells in culture (5, and our own unpublished observations). Previous studies have demonstrated that oxidants generated by stimulated leukocytes can induce DNA strand breaks, sister chromatid exchanges, mutations, or damage to guanine or thymine bases in cells or in isolated DNA (6-13). The predominant extracellular oxidant responsible for neutrophil-induced DNA damage in target cells appears to be hydrogen peroxide, $\left(\mathrm{H}_{2} \mathrm{O}_{2}\right)(14,15)$. Data indicate that $\mathrm{H}_{2} \mathrm{O}_{2}$ diffuses into cells, and in the presence of a transition metal ion such as iron ion, generates hydroxyl radicals $\left({ }^{\circ} \mathrm{OH}\right)$ in close proximity to DNA $(14,15)$. Hydroxyl radicals could, therefore, be the intracellular oxidant ultimately responsible for DNA damage (14-17). Since elucidation of the chemical nature of neutrophil-induced DNA damage may enhance our understanding of the mechanisms underlying neutrophil-induced DNA damage and the carcinogenesis associated with inflammation, the present study was undertaken to characterize the chemical modifications that occur in DNA exposed to stimulated human neutrophils.

\section{Methods}

Separation and purification of human neutrophils. Blood was obtained from healthy human donors and anticoagulated with acid citrate dextrose. Neutrophils were separated and purified from fresh human blood by counterflow centrifugal elutriation, as previously de-scribed (18).

Treatment of DNA with neutrophils. Calf thymus DNA $(1 \mathrm{mg}$; Sigma Chemical Co., St. Louis, MO) was incubated with neutrophils (4 $\times 10^{6} / \mathrm{ml}$ ), phorbol myristate acetate (PMA, $500 \mathrm{ng} / \mathrm{ml}$ ), and/or $\mathrm{FeSO}_{4} / \mathrm{EDTA}(10 \mu \mathrm{M} / 20 \mu \mathrm{M}$, all from Sigma $)$ in a final volume of 100 $\mathrm{ml}$ of $\mathrm{PBS}$ for $30 \mathrm{~min}$ at $37^{\circ} \mathrm{C}$. In selected experiments, deferoxamine (500 $\mu \mathrm{M}$; CIBA-Geigy, Basel, Switzerland), dimethylsulfoxide (DMSO, $375 \mathrm{mM}$; Sigma), superoxide dismutase (SOD, $150 \mu \mathrm{g} / \mathrm{ml}$; Sigma), heat inactivated SOD $(150 \mu \mathrm{g} / \mathrm{ml})$, catalase $(375 \mu \mathrm{g} / \mathrm{ml}$; Sigma), or heat-inactivated catalase $(375 \mu \mathrm{g} / \mathrm{ml})$ was added to reaction mixtures before the addition of PMA, neutrophils, and/or $\mathrm{FeSO}_{4} /$ EDTA. After incubation, reaction mixtures were centrifuged at $500 \mathrm{~g}$ for $10 \mathrm{~min}$ to pellet the neutrophils. The supernatant was removed, and DNA was precipitated with ethanol, dialyzed against water, and lyophilized.

Hydrolysis and derivatization of DNA samples. DNA samples (1 $\mathrm{mg}$ ) were hydrolyzed with $1 \mathrm{ml}$ of formic acid (88\%; Mallinckrodt Inc., Paris, KY) in evacuated and sealed tubes at $150^{\circ} \mathrm{C}$ for $30 \mathrm{~min}$. After hydrolysis, samples were lyophilized and trimethylsilylated with 0.25 $\mathrm{ml}$ of a 1.5:1 mixture of bis(trimethylsilyl)trifluoroacetamide (BSTFA, containing $1 \%$ trimethylchlorosilane; Pierce Chemical Co., Rockford, 
IL) and acetonitrile, in polytetrafluoroethylene capped hypovials (both from Pierce Chemical Co.) by heating at $130^{\circ} \mathrm{C}$ for $30 \mathrm{~min}$.

Chemical characterization of DNA base damage. Hydrolyzed and derivatized DNA samples were analyzed by gas chromatography-mass spectrometry with selected-ion monitoring (GC-MS/SIM) ${ }^{1}$ according to previously described methods $(19,20)$. Briefly, for analysis of DNA samples, a mass selective detector controlled by a computer work station and interfaced to a gas chromatograph (all instruments from Hewlett-Packard Co., Avondale, PA, with model numbers 5970B, $59970 \mathrm{C}$, and $5890 \mathrm{~A}$, respectively) was used. The injection port and the ion source were kept at $250^{\circ} \mathrm{C}$. The GC-MS interface was maintained at $270^{\circ} \mathrm{C}$. Separations were carried out on a fused silica capillary column (12.5 m $\times 0.32 \mathrm{~mm}$ i.d.) coated with crosslinked 5\% phenyl methyl silicone gum phase (film thickness, $0.17 \mu \mathrm{m}$ ). The column was programmed from $120^{\circ}$ to $250^{\circ} \mathrm{C}$ at $8^{\circ} \mathrm{C} / \mathrm{min}$, after $2 \mathrm{~min}$ at $120^{\circ} \mathrm{C}$. Helium was used as the carrier gas at an inlet pressure of $10 \mathrm{kPa}$. Samples were injected using the split mode. Mass spectra were obtained at $70 \mathrm{eV}$. Authentic samples of isobarbituric acid (5-hydroxyuracil, Sigma), 4,6-diamino-5-formamidopyrimidine (Sigma), and 2amino-6,8-dihydroxy-purine (8-hydroxyguanine; Chemical Dynamics Corp., South Plainfield, NJ), were available commercially. 8-hydroxyadenine and 2,6-diamino-4-hydroxy-5-formamidopyrimidine were synthesized as previously described (21). Thymine glycol was kindly provided by Dr. W. F. Blakely of the Armed Forces Radiobiology Research Institute, Bethesda, MD.

Quantitation of DNA base damage. DNA base products were quantitatively measured using 6-azathymine and 8-azaadenine (both from Sigma Chemical Co.) as internal standards, and using the GC-MS/SIM technique as previously described (21). Aliquots of the internal standards were added to aliquots of DNA samples. The samples were then lyophilized, hydrolyzed, trimethylsilylated, and analyzed by GC-MS/ SIM. Ion currents of the typical ions of the DNA base products were monitored along with those of the $\mathrm{m} / \mathrm{z} 256$ ion of the trimethyl-silyl derivative of 6-azathymine, and the $\mathrm{m} / \mathrm{z} 265$ ion of the trimethylsilyl derivative of 8-azaadenine.

Measurement of oxidant release from stimulated neutrophils. Oxidant release from stimulated neutrophils was assessed by measuring superoxide anion $\left(\mathrm{O}_{\overline{2}}\right)$ or $\mathrm{H}_{2} \mathrm{O}_{2}$ production. Neutrophils $\left(4 \times 10^{6} / \mathrm{ml}\right)$ were incubated with PMA $(500 \mathrm{ng} / \mathrm{ml})$ in the presence or absence of deferoxamine $(500 \mu \mathrm{M})$ or DMSO $(375 \mathrm{mM})$ for $30 \mathrm{~min}$ at $37^{\circ} \mathrm{C} . \mathrm{O}_{\overline{2}}^{\overline{2}}$ production was measured by assaying superoxide dismutase inhibitable cytochrome $c$ reduction (22), and $\mathrm{H}_{2} \mathrm{O}_{2}$ production was measured by fluorescence spectroscopy utilizing the peroxidase parahydroxyphenyl acetic acid assay (23).

\section{Results}

Chemical characterization of DNA base damage. Fig. $1 A$ and $B$ illustrates the ion-current profiles at mass/charge $(\mathrm{m} / \mathrm{z}) 329$, $328,259,354,352,442$, and 440 obtained by GC-MS/SIM analysis of DNA exposed to PMA-stimulated neutrophils in the presence of iron ions, and untreated DNA, respectively. Peaks 1-8 were identified as the trimethylsilyl $\left(\mathrm{Me}_{3} \mathrm{Si}\right)$ derivatives of 5-hydroxyuracil, 5-hydroxycytosine, cis-thymine glycol, trans-thymine glycol, 4,6-diamino-5-formamidopyrimidine, 8-hydroxyadenine, 2,6-diamino-4-hydroxy-5-formamidopyrimidine, and 8-hydroxyguanine, respectively. The compounds 5-hydroxyuracil and 5-hydroxycytosine result from either the dehydration and deamination, or dehydration, respectively, of cytosine glycol, which is the actual ${ }^{\circ} \mathrm{OH}$ induced product of cytosine (19). The chemical structures of these modified DNA bases are shown in Fig. 2. Although Fig. 1

1. Abbreviations used in this paper: GC-MS/SIM, gas chromatography-mass spectrometry with selected-ion monitoring.

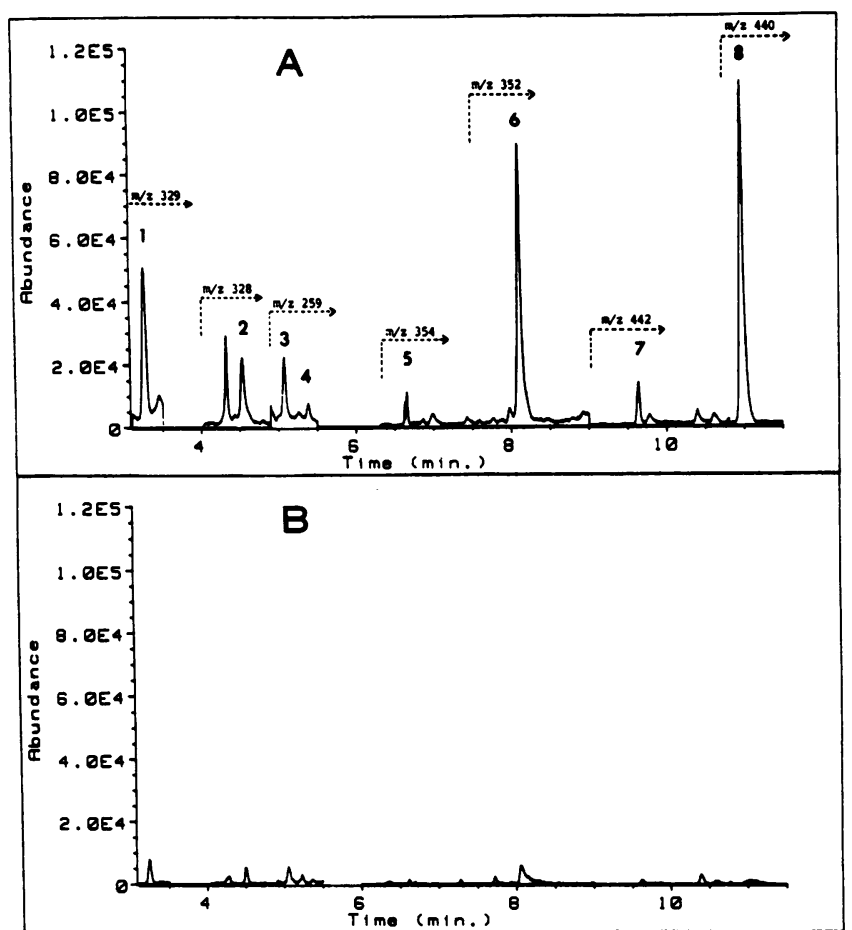

Figure 1. Identification of modified bases in DNA. Ion current profiles of the ions at $\mathrm{m} / \mathrm{z} 329,328,259,354,352,442$, and $440 \mathrm{ob}-$ tained from trimethylsilylated hydrolysates of DNA. $(A)$ DNA $(1 \mathrm{mg})$ exposed to PMA $(500 \mathrm{ng} / \mathrm{ml})$, neutrophils $\left(4 \times 10^{6} / \mathrm{ml}\right)$ and $\mathrm{FeSO}_{4} /$ EDTA $(10 \mu \mathrm{M} / 20 \mu \mathrm{M})$ in a final volume of $100 \mathrm{ml}$ of PBS for 30 min at $37^{\circ} \mathrm{C}$. (B). Untreated DNA. Peak identification: 1. 5-hydroxyuracil; 2. 5-hydroxycytosine; 3. cis-thymine glycol; 4. trans-thymine glycol; 5. 4,6-diamino-5-formamidopyrimidine; 6. 8-hydroxyadenine; 7. 2,6-diamino-4-hydroxy-5-formamidopyrimidine; 8. 8-hydroxyguanine (all compounds as their $\mathrm{Me}_{3} \mathrm{Si}$ derivatives). Arrows indicate time intervals for each ion monitored.

$A$ illustrates only one ion for each compound, a number of characteristic ions from the known mass spectra of each compound $(20,24)$ were monitored at the various time intervals indicated by the arrows in Fig. $1 A$. For identification, partial mass spectra obtained from peaks 1 to 8 were compared with spectra obtained from authentic compounds. As an example,

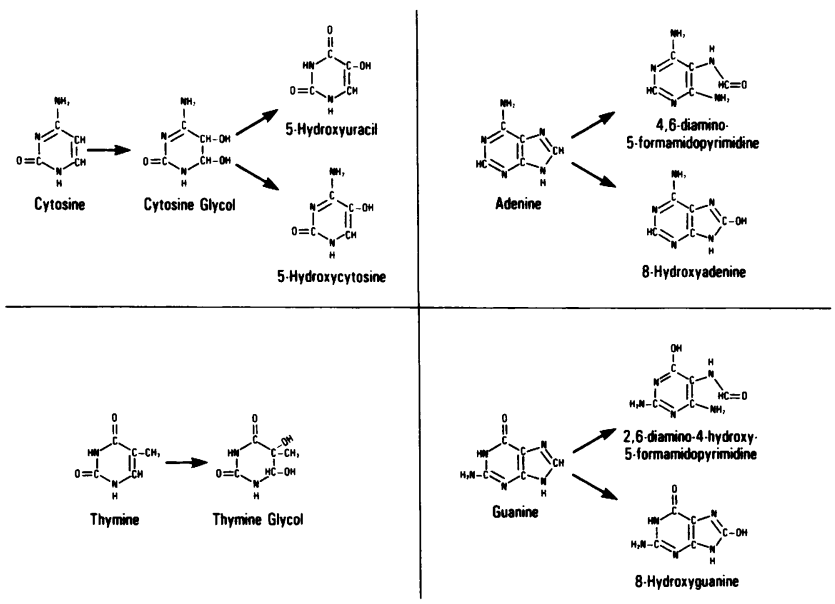

Figure 2. Chemical structures of modified bases identified in DNA. 
Fig. $3 A$ illustrates the partial mass spectrum obtained from peak 5 in Fig. $1 A$. This spectrum can be directly correlated to the mass spectrum of the $\mathrm{Me}_{3} \mathrm{Si}$ derivative of 4,6-diamino-5formamidopyrimidine, illustrated in Fig. $3 \mathrm{~B}$. Similarly, the partial mass spectra obtained from peaks $1-4$, and 6-8 were also correlated to the mass spectra of the corresponding authentic compounds (data not shown).

Quantitation of DNA base damage. The yields of the base products in various DNA samples are illustrated in Fig. 4. Low quantities of the DNA base products were seen in untreated DNA. The presence of low quantities of typical ${ }^{\circ} \mathrm{OH}$ induced base products in untreated DNA has been reported previously (25). DNA treated with $\mathrm{FeSO}_{4} /$ EDTA, PMA, or unstimulated neutrophils, also had low quantities of these products. In contrast, DNA exposed to PMA-stimulated neutrophils had greater quantities of DNA base products, which were further increased by the addition of $\mathrm{FeSO}_{4} /$ EDTA to incubation mixtures.

The effect of the ${ }^{\circ} \mathrm{OH}$ scavenger, DMSO, the iron chelator, deferoxamine, the $\mathrm{O}_{\overline{2}}$ scavenger, $\mathrm{SOD}$, or the $\mathrm{H}_{2} \mathrm{O}_{2}$ scavenger, catalase, on the yields of DNA base products in DNA exposed to PMA, neutrophils and $\mathrm{FeSO}_{4} /$ EDTA is shown in Table I. DMSO and deferoxamine significantly decreased the yields of all of the DNA base products. SOD or catalase (but not heatinactivated SOD or heat-inactivated catalase) decreased the yields of some DNA base products. (We were unable to assess the effect of SOD or catalase on all of the DNA base products, because the addition of SOD or catalase to samples yielded signals from unknown compounds with retention times that were at or near the retention times of signals from some of the DNA base products. These unknown compounds thus interfered with the proper integration of signals from these DNA base products.)

Measurement of oxidant release from stimulated neutrophils. To insure that deferoxamine or DMSO did not inhibit oxidant release from stimulated neutrophils, we measured the amount of $\mathrm{O}_{\overline{2}}^{\bar{z}}$ or $\mathrm{H}_{2} \mathrm{O}_{2}$ produced by PMA-stimulated neutrophils in the presence or absence of deferoxamine or DMSO. In the presence of deferoxamine, PMA-stimulated neutrophils released $98.3 \pm 2.4 \%$ of the amount of $\mathrm{O}_{\overline{2}}^{\overline{2}}$ released from PMAstimulated neutrophils incubated in the absence of deferoxamine. Similarly, in the presence of DMSO, PMA-stimulated neutrophils released $105.8 \pm 4.7 \%$ of the amount of $\mathrm{H}_{2} \mathrm{O}_{2}$ re-

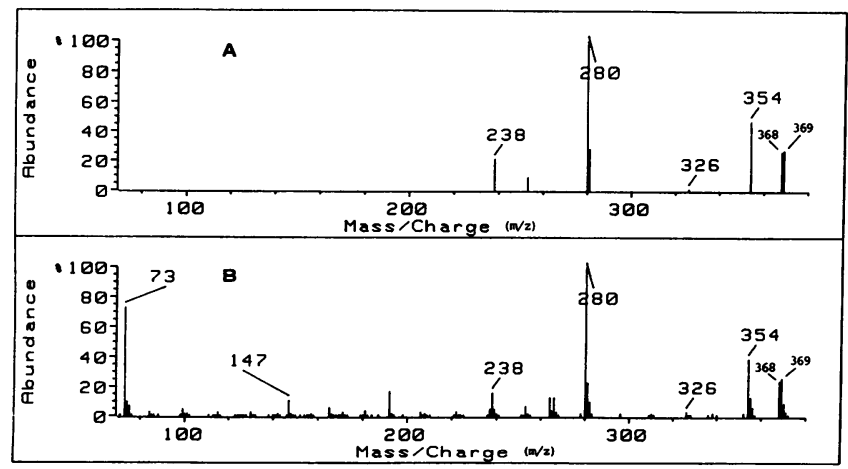

Figure 3. Mass spectra of modified DNA bases. $(A)$. Partial mass spectrum obtained from the monitored ions and their abundances at the elution position of peak 5 in Fig. $1 A$. $(B)$. Mass spectrum of the $\mathrm{Me}_{3} \mathrm{Si}$ derivative of authentic 4,6-diamino-5-formamidopyrimidine.

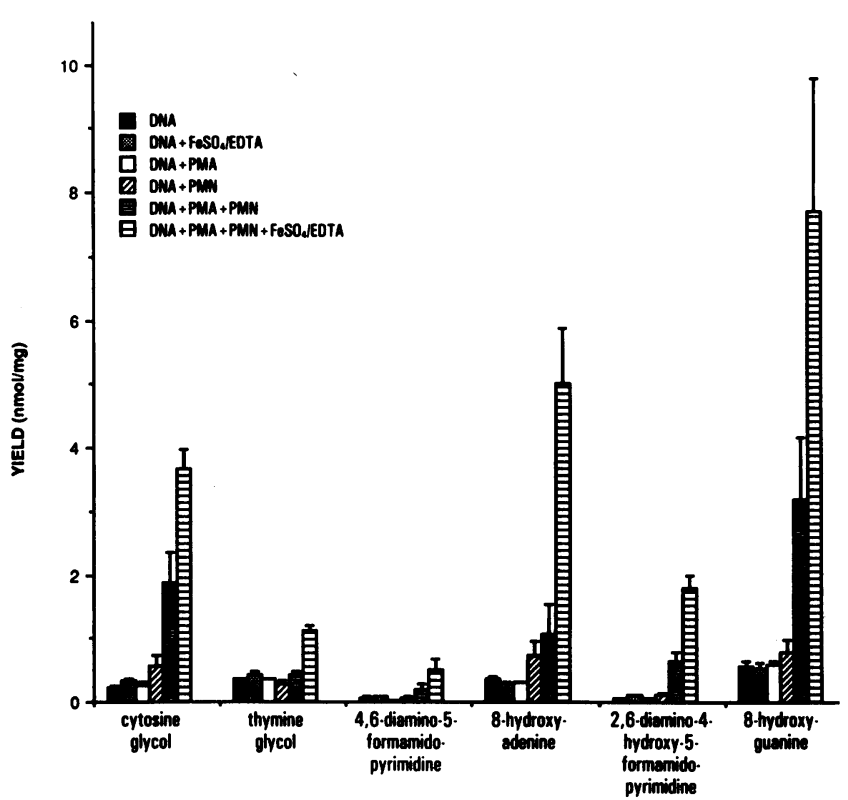

Figure 4. Yields of the base products in DNA. Reaction conditions were the same as those given in Fig. 1. Each data point represents the mean $( \pm \mathrm{SD})$ from at least three independent experiments.

leased from PMA-stimulated neutrophils incubated in the absence of DMSO.

\section{Discussion}

The GC-MS/SIM data presented in this work indicate that stimulated neutrophils can damage each of the four bases in DNA. In the presence of physiologic amounts of neutrophils and iron ions, $\sim 7$ of every 1,000 DNA bases were modified. Two of the base products identified in the present study have previously been reported to occur in DNA exposed to or extracted from stimulated neutrophils $(11,12)$. Our study differs from these previous studies in several major ways. First, these previous studies identified only two (8-hydroxyguanine and thymine glycol) of the six base products identified in our study. Moreover, since it has not been previously demonstrated that neutrophils can damage adenine or cytosine, our study is, as far as we know, the first report that demonstrates that stimulated neutrophils can damage each of the four bases in DNA. Second, our study documents the quantity of neutrophil-induced DNA damage that occurs to each of the four DNA bases. As can be seen in Fig. 4, 8-hydroxyguanine, 8-hydroxyadenine, and cytosine glycol appear to be major neutrophilinduced DNA base damage products, followed by 2,6-diamino-4-hydroxy-5-formamidopyrimidine, thymine glycol, and 4,6-diamino-5-formamidopyrimidine. Third, previous investigators utilized HPLC with ultraviolet, radiochemical, and/or electrochemical detection $(11,12)$ to detect neutrophil-induced DNA base modifications, and identification of these modified bases was based solely on the observation of peaks that co-eluted with known standards. Although these HPLC methods are certainly useful, the possibility exists that compounds other than modified bases could co-elute with standards and be erroneously identified as modified bases. These HPLC techniques do not, therefore, provide definitive proof that these modified DNA bases were formed in the pres- 
Table I. Effect of the ${ }^{\circ} \mathrm{OH}$ Scavenger, DMSO, the Iron Chelator, Deferoxamine, the $\mathrm{O}_{\overline{2}}$ Scavenger, $\mathrm{SOD}$, and the $\mathrm{H}_{2} \mathrm{O}_{2} \mathrm{Scavenger}_{\text {, }}$ Catalase, on Neutrophil-Induced DNA Base Modifications

\begin{tabular}{|c|c|c|c|c|c|c|}
\hline \multirow[b]{2}{*}{ Modified base } & \multicolumn{6}{|c|}{ \% Reduction of DNA Base Modifications* } \\
\hline & DMSO & Deferoxamine & $\begin{array}{l}\text { Active } \\
\text { SOD }\end{array}$ & $\begin{array}{l}\text { Inactive } \\
\text { SOD }\end{array}$ & $\begin{array}{c}\text { Active } \\
\text { catalase }\end{array}$ & $\begin{array}{l}\text { Inactive } \\
\text { catalase }\end{array}$ \\
\hline Cytosine glycol & $76 \pm 16^{\ddagger}$ & $72 \pm 28$ & $69 \pm 29$ & $8 \pm 11$ & $\S$ & $\S$ \\
\hline Thymine glycol & $76 \pm 21$ & $94 \pm 6$ & $58 \pm 18$ & $23 \pm 17$ & $100 \pm 0$ & $17 \pm 12$ \\
\hline 4,6-Diamino-5-formamidopyrimidine & $97 \pm 4$ & $81 \pm 31$ & $94 \pm 7$ & 0 & $100 \pm 0$ & 0 \\
\hline 8-Hydroxyadenine & $92 \pm 6$ & $100 \pm 0$ & $42 \pm 21$ & $11 \pm 9$ & $\S$ & $\S$ \\
\hline 2,6-Diamino-4-hydroxy-5-formamidopyrimidine & $93 \pm 7$ & $71 \pm 29$ & $97 \pm 4$ & $24 \pm 34$ & $\S$ & $\S$ \\
\hline 8-Hydroxyguanine & $100 \pm 0$ & $100 \pm 0$ & $\S$ & $\S$ & $\S$ & $\S$ \\
\hline
\end{tabular}

* $100 \%$ indicates reduction of DNA base damage to conrol values. $\quad{ }^{\ddagger}$ Values are means \pm SD. ${ }^{\S}$ SOD and/or catalase interfered with GC-MS/ SIM measurement of these base products.

ence of stimulated neutrophils. We believe that the GC-MS/ SIM method employed in this work is superior to the aforementioned HPLC methods, since the identification of modified bases is not only based on the co-elution of compounds with known standards, but is also directly confirmed by comparing the mass spectra of these compounds with the mass spectra of known standards. In this regard, it should be noted that another thymine base product, 5-hydroxymethyluracil, which was previously detected by HPLC in single-stranded DNA exposed to stimulated neutrophils (11), was not detected in this study. Since the GC-MS technique is capable of detecting this compound (24), it appears that under our experimental conditions 5-hydroxymethyluracil was either not formed, or was formed in levels below the limit of detectability.

Several lines of evidence suggest that ${ }^{\circ} \mathrm{OH}$ may be responsible for neutrophil-induced DNA base damage. First, addition of the ${ }^{\circ} \mathrm{OH}$ scavenger, DMSO, significantly decreased the yield of each of the neutrophil-induced DNA base products. Second, addition of the $\mathrm{O}_{\overline{2}}$ scavenger, SOD, or the $\mathrm{H}_{2} \mathrm{O}_{2}$ scavenger, catalase, (but not heat-inactivated SOD or catalase) decreased the quantity of neutrophil-induced DNA base damage. Since both $\mathrm{O}_{\overline{2}}$ and $\mathrm{H}_{2} \mathrm{O}_{2}$ are required to generate ${ }^{\circ} \mathrm{OH}$ via the iron catalyzed Haber-Weiss reaction:

$\mathrm{O}_{\overline{2}}+\mathrm{Fe}^{3+} \rightarrow \mathrm{O}_{2}+\mathrm{Fe}^{2+}$

$\mathrm{H}_{2} \mathrm{O}_{2}+\mathrm{Fe}^{2+} \rightarrow \cdot \mathrm{OH}+\mathrm{OH}^{-}+\mathrm{Fe}^{3+}$

SOD and catalase likely decreased neutrophil-induced DNA base damage by decreasing ${ }^{\circ} \mathrm{OH}$ production. Third, addition of physiologic quantities of iron ions significantly increased the quantity of neutrophil-induced DNA base damage. Since iron ions serve as catalysts for ${ }^{\circ} \mathrm{OH}$ production in the modified Haber-Weiss reaction, iron ions likely increased neutrophilinduced DNA base damage by increasing ${ }^{\circ} \mathrm{OH}$ production. The small amount of DNA base damage observed in the presence of stimulated neutrophils, but in the absence of exogenously added iron ions, likely reflects contamination of DNA and/or buffer solutions with trace amounts of metal ions. This premise is supported by the observation that DNA exposed to high concentrations of $\mathrm{H}_{2} \mathrm{O}_{2}(50-400 \mathrm{mM})$ in buffer in which contaminating iron ions had not been removed developed a pattern of base modifications characteristic of ${ }^{\circ} \mathrm{OH} .{ }^{2}$ Fourth, the

2. Blakely, W. F., A. F. Fuciarelli, B. J. Wegher, and M. Dizdaroglu. Manuscript submitted for publication. iron chelator, deferoxamine, prevented neutrophil-induced DNA base damage (Table I). Since iron chelated by deferoxamine can not effectively catalyze ${ }^{\circ} \mathrm{OH}$ production, deferoxamine likely decreased neutrophil-induced DNA base damage by decreasing ${ }^{\circ} \mathrm{OH}$ production. Fifth, each of the base modifications that we detected in DNA exposed to stimulated neutrophils has been previously detected in DNA exposed to ionizing radiation in nitrous oxide $\left(\mathrm{N}_{2} \mathrm{O}\right)$-saturated aqueous solutions (20). Ionizing radiation in $\mathrm{N}_{2} \mathrm{O}$-saturated aqueous solutions generates $\sim 90 \%{ }^{\circ} \mathrm{OH}$ and $10 \%$ hydrogen atoms $\left(\mathrm{H}^{\circ}\right)$ (28). Accordingly, the vast majority of DNA base modifications induced by ionizing radiation in $\mathrm{N}_{2} \mathrm{O}$ saturated aqueous solutions are secondary to $\mathrm{OH}$ formation, and only a few DNA base modifications are secondary to $\mathrm{H}^{\circ}$ formation (20). Since each of the base modifications detected in DNA exposed to stimulated neutrophils were identical to base modifications known to be induced by ionizing radiation-generated ${ }^{\circ} \mathrm{OH}$, and none of the base modifications known to be induced by ionizing radiation-generated $\mathrm{H}^{*}$ were detected in DNA exposed to stimulated neutrophils; these observations provide further support that ${ }^{\circ} \mathrm{OH}$ likely mediates neutrophil-induced DNA base damage.

Interestingly, the relative quantities of ${ }^{\circ} \mathrm{OH}$-mediated, neutrophil-induced DNA base damage products (Fig. 4) differ from the relative quantities of DNA base damage products induced by radiation generated $\mathrm{OH}$. (Measurement of radiation-induced base products in DNA was performed by GC-MS/SIM under conditions identical to those employed to measure neutrophil-induced base products in DNA. ${ }^{3}$ ) 8-hydroxyguanine and 2,6-diamino-4-hydroxy-5-formamidopyrimidine are the major base products detected when doublestranded DNA is exposed to radiation-generated ${ }^{\circ} \mathrm{OH}$ in $\mathrm{N}_{2} \mathrm{O}$ saturated aqueous solutions. ${ }^{3}$ The yields of these two major products are followed by roughly equal yields of cytosine glycol, thymine glycol, and 4,6-diamino-5-formamidopyrimidine, and these products are followed by 8-hydroxyadenine, which has the lowest yield of all of the radiation-induced DNA base products. ${ }^{3}$ In contrast, 8 -hydroxyadenine is a major product while 2,6-diamino-4-hydroxy-5-formamidopyrimidine, 4,6-diamino-5-formamidopyrimidine and thymine glycol appear to be only minor products of neutrophil-induced DNA

3. Fuciarelli, A. F., B. J. Wegher, W. F. Blakely, and M. Dizdaroglu. Manuscript submitted for publication. 
base damage. The reason for these apparent differences in the sensitivity of DNA bases to ${ }^{\circ} \mathrm{OH}$ generated by stimulated neutrophils as opposed to ionizing radiation is unknown. It is possible, however, that these differences may reflect the different mechanisms of ${ }^{\circ} \mathrm{OH}$ production with stimulated neutrophils vs. ionizing radiation. For instance, radiation of DNA in aqueous solution could conceivably generate ${ }^{\circ} \mathrm{OH}$ at any point along the DNA, while stimulated neutrophils might only be expected to generate ${ }^{\circ} \mathrm{OH}$ at sites along the DNA where iron ions and neutrophil-derived oxidants are within a distance of 6 nm of the DNA.

The ability of SOD, catalase or deferoxamine to prevent DNA damage in the present study suggests that $\mathrm{O}_{\overline{2}}, \mathrm{H}_{2} \mathrm{O}_{2}$, and iron ions must all be present in close proximity to the DNA for DNA damage to occur. Similarly, the extremely high concentrations of reagent $\mathrm{H}_{2} \mathrm{O}_{2}(50-400 \mathrm{mM})$ required to cause base damage of isolated DNA in the absence of exogenously added $\mathrm{O}_{\overline{2}}^{\bar{z}}$ or iron ions, ${ }^{2}$ underscores the importance of all three of these components in isolated DNA model systems. However, in the case of intact cells, $\mathrm{O}_{\overline{2}}^{\bar{z}}$ may not be required for DNA damage, since intact cells contain other reductants which could potentially substitute for $\mathrm{O}_{\dot{2}}^{-}$and reduce $\mathrm{Fe}^{3+}$ to $\mathrm{Fe}^{2+}$. It is likely, therefore, that neutrophil-derived $\mathrm{H}_{2} \mathrm{O}_{2}$ diffuses into cells, reacts with $\mathrm{Fe}^{2+}$ that is either in close proximity to or bound to DNA, and generates ${ }^{\circ} \mathrm{OH}$, which can in turn cause DNA base damage $(14,15)$.

The concentration of neutrophils employed in the present study causes potentially reversible cell injury (10). Although DNA damage in living cells is subject to cellular repair (10, 29), DNA damage may occasionally escape repair, or its repair may be incorrect. In these instances, unrepaired or mis-repaired DNA damage could have deleterious consequences. For example, recent studies with several DNA base damage products (8-hydroxyguanine, thymine glycol, and 5-hydroxymethyluracil) have demonstrated that these modified bases can cause DNA base mispairing and/or constitute replicative blocks to DNA synthesis by DNA polymerases (30-33). In addition, previous studies have demonstrated that stimulated neutrophils transform mouse fibroblast cells into malignant cells ( 5 , and our own unpublished observations). These studies suggest that neutrophil-induced DNA base damage could underlie gene modifications that could ultimately promote cellular transformation. Neutrophil-induced DNA base damage, likely mediated by ${ }^{\circ} \mathrm{OH}$, may, therefore, form the basis (at least in part) for the known relationship between chronic inflammation and malignancy.

\section{Acknowledgments}

The authors wish to acknowledge the excellent technical assistance of Ms. Chao Yu Kuo, Mr. Chris Caldwell, and Ms. Cathy Case, and the excellent secretarial assistance of Ms. Monica Bartlett.

This work was supported in part by funds from U. S. Public Health Service and by a fellowship from the Parker B. Francis Foundation to Dr. Jackson. We thank Dr. Barry Halliwell of the King's College London University for a critical review of the manuscript.

\section{References}

1. Templeton, A. C. 1975. Acquired diseases. In Persons at High Risk of Cancer. An Approach to Cancer Etiology and Control. J. F. Fraumeni, Jr., editor. Academic Press, New York. 69-84.
2. Ames, B. N. 1983. Dietary carcinogens and anticarcinogens. Oxygen radicals and degenerative diseases. Science. (Wash. DC). 221:1256-1264.

3. Cerutti, P. A. 1985. Prooxidant states and tumor promotion. Science (Wash. DC). 227:375-381.

4. Alexander-Williams, J. 1976. Inflammatory disease of the bowel. The risk of cancer. Dis. Colon Rectum. 19:579-581.

5. Weitzman, S. A., A. B. Weitberg, E. P. Clark, and T. P. Stossel. 1985. Phagocytes as carcinogens: malignant transformation produced by human neutrophils. Science (Wash. DC). 227:1231-1233.

6. Weitberg, A. B., S. A. Weitzman, M. Destrempes, S. A. Latt, and T. P. Stossel. 1983. Stimulated human phagocytes produce cytogenetic changes in cultured mammalian cells. $N$. Engl. J. Med. 308:26-29.

7. Weitzman, S. A., and T. P. Stossel. 1982. Effects of oxygen radical scavengers and antioxidants on phagocyte-induced mutagenesis. J. Immun. 128:2770-2772.

8. Birnboim, H. C. 1982. DNA strand breakage in human leukocytes exposed to a tumor promoter, phorbol myristate acetate. Science (Wash. DC). 215:1247-1249.

9. Lewis, J. G., and D. O. Adams. 1985. Induction of 5,6, ring-saturated thymine bases in NIH $3 \mathrm{~T} 3$ cells by phorbol ester-stimulated macrophages: role of reactive oxygen intermediates. Cancer Res. 45:1270-1275.

10. Schraufstatter, I. U., D. B. Hinshaw, P. A. Hyslop, R. G. Spragg, and C. G. Cochrane. 1986. Oxidant Injury of Cells. DNA strand breaks activate polyadenosine diphosphate-ribose polymerase and lead to depletion of nicotinamide adenine dinucleotide. J. Clin. Invest. 77:1312-1320.

11. Frenkel, K., K. Chrzan, W. Troll, G. W. Teebor, and J. J. Steinberg. 1986. Radiation like modification of bases in DNA exposed to tumor promoter-activated polymorphonuclear leukocytes. Cancer Res. 46:5533-5540.

12. Floyd, R. A., J. J. Watson, J. Harris, M. West, and P. K. Wong. 1986. Formation of 8-hydroxy-deoxyguanosine, hydroxyl free radical adduct of DNA in granulocytes exposed to tumor promoter, tetra deconyl phorbol acetate. Biochem. Biophys. Res. Commun. 137:841846.

13. Schraufstatter, I. U., P. A. Hyslop, D. B. Hinshaw, R. G. Spragg, L. A. Sklar, and C. G. Cochrane. 1986. Hydrogen peroxide-induced injury of cells and its prevention by inhibitors of poly (ADP-ribose) polymerase. Proc. Natl. Acad. Sci. USA. 83:4908-4912.

14. Halliwell, B. 1987. Oxidants and human disease: some new concepts. FASEB (Fed. Am. Soc. Eur. Biol.) J. 1:358-364.

15. Schraufstatter, I. U., P. A. Hyslop, J. H. Jackson, and C. G. Cochrane. 1988. Oxidant induced DNA damage of target cells. J. Clin. Invest. 82:1040-1050.

16. Jackson, J. H., I. U. Schraufstatter, P. A. Hyslop, K. Vosbeck, R. Sauerheber, S. A. Weitzman, and C. G. Cochrane. 1987. Role of oxidants in DNA damage. Hydroxyl radical mediates the synergistic DNA damaging effects of asbestos and cigarette smoke. J. Clin. Invest. 80:1090-1095.

17. Filho, A. C. M., R. Meneghini. 1985. Protection of mammalian cells by o-phenanthroline from lethal and DNA damaging effects produced by active oxygen species. Biochim. Biophys. Acta. 847:82-89.

18. Berkow, R. L., D. Y. Tzeng, L. V. Williams, and R. L. Baehner. 1983. The comparative responses of human polymorphonuclear leukocytes obtained by counterflow centrifugal elutriation and Ficoll-Hypaque density centrifugation. J. Lab. Clin. Med. 102:732-742.

19. Dizdaroglu, M. 1986. Chemical characterization of ionizing radiation-induced damage to DNA. Biotechniques. 4:536-546.

20. Dizdaroglu, M. 1985. Application of capillary gas chromatography-mass spectrometry to chemical characterization of radiation-induced base damage to DNA: implications for assessing DNA repair processes. Anal. Biochem. 144:593-603.

21. Fuciarelli, A. F., B. J. Wegher, E. Gajewski, M. Dizdaroglu, and W. F. Blakely. 1989. Quantitative measurement of radiation-induced base products in DNA using gas chromatography-mass spectrometry. Rad. Res. 119:219-231. 
22. Curnutte, J. T., D. M. Whitten, and B. M. Babior. 1974. Defective superoxide production by granulocytes from patients with chronic granulomatous disease. N. Engl. J. Med. 290:593-597.

23. Guilbault, E. C., P. J. Brignac, Jr., and J. Juneau. 1986. New substrates for the fluorometric determination of oxidative enzymes Anal. Chem. 40:1256-1261.

24. Dizdaroglu, M. 1984. The use of capillary gas-chromatography-mass spectrometry for identification of radiation-induced DNA base damage and DNA base-amino acid crosslinks. J. Chromatogr. 295:103-121.

25. Dizdaroglu, M., and D. S. Bergtold. 1986. Characterization of free radical-induced base damage in DNA at biologically relevant levels. Anal. Biochem. 156:182-188.

26. McCord, J. M., and E. E. Day, Jr. 1978. Superoxide-dependent production of hydroxyl radical catalyzed by the iron-EDTA complex. FEBS (Fed. Eur. Biochem. Soc.) Lett. 86:139-142.

27. Halliwell, B. 1978. Superoxide dependent formation of hydroxyl radicals in the presence of iron chelates. Is it a mechanism for hydroxyl radical production in biological systems? FEBS (Fed. Eur. Biochem. Soc.) Lett. 92:321-326.

28. von Sonntag, C. 1987. The Chemical Basis of Radiation Biology. Taylor and Francis, London.

29. Friedberg, E. C. 1985. DNA repair. W. H. Freeman and Co., New York.

30. Kuchino, Y., F. Mori, H. Kasai, H. Inoue, S. Iwai, K. Miura, E. Ohtsuka, and S. Nishimura. 1987. Misreading of DNA templates containing 8-hydroxy-deoxyguanosine at the modified base and at adjacent residues. Nature (Lond.). 327:77-79.

31. Clark, J. M., and G. P. Beardsley. 1987. Functional effects of cis-thymine glycol lesions on DNA synthesis in vitro. Biochemistry. 26:5398-5403.

32. Wallace, S. S. 1987. The biological consequences of oxidized DNA bases. Br. J. Cancer. 55(Suppl. VIII):118-128.

33. Shirname-More, L., T. G. Rossman, W. Troll, G. W. Teebor, and K. Frenkel. 1987. Genetic effects of 5-hydroxy-methyl-2-deoxyuridine, a product of ionizing radiation. Mut. Res. 178:177-186.

\section{Editor's Note}

This issue of the Journal of Clinical Investigation includes a paper by Jackson, Gajewski, Fuciarelli, Schraufstatter, Hyslop, Cochrane, and Dizdaroglu entitled "Damage to the bases in DNA induced by stimulated human neutrophils." This paper, which was first received by the JCI editorial office in July of 1988, represents a collaborative effort by investigators at the Department of Immunology at the Scripps Research Institute in La Jolla, California and the Center for Chemical Technology at the National Institute of Standards and Technology in Gaithersburg, Maryland. In March of 1989, Drs. Aruoma, Halliwell, and Dizdaroglu from the National Institute of Standards and Technology submitted an article to the Journal of Biological Chemistry entitled "Iron ion-dependent modification of bases in DNA by the superoxide radical-generating system hypoxanthine/xanthine oxidase." This paper appeared in the August 5th issue of the JBC (264:13024-13028).

At the time of submission of this manuscript to the JBC, neither the Editors of the JBC nor the Editors of the JCI were made aware of the two manuscripts under review, and the manuscripts were not cross-referenced. The Editors of the JCI were first notified about the JBC paper shortly after its publication in August by Drs. Jackson and Cochrane, who indicate that they and their colleagues at the Scripps were also previously unaware of the existence of this paper.

Dr. Dizdaroglu, the author common to these two papers, indicates that he feels the two manuscripts are neither closely related nor similar, and he therefore did not think it necessary to notify the Editors. The Editors of the JCI hold a different view. We feel these two manuscripts, which differ primarily in the system used to generate reactive oxygen species, are very similar and that the Editors should have been notified.

We therefore call these two manuscripts to the attention of our readers and underscore the importance of clear communication among authors and editors. 